\title{
Review of Julie V. Gottlieb 'Guilty Women', foreign policy, and appeasement in inter-war Britain.
}

\section{Marc Calvini Lefebvre}

\section{(2) OpenEdition}

\section{Journals}

Electronic version

URL: http://journals.openedition.org/rfcb/874

DOI: $10.4000 / \mathrm{rfcb} .874$

ISSN: 2429-4373

\section{Publisher}

CRECIB - Centre de recherche et d'études en civilisation britannique

\section{Electronic reference}

Marc Calvini Lefebvre, «Review of Julie V. Gottlieb 'Guilty Women', foreign policy, and appeasement in inter-war Britain. », Revue Française de Civilisation Britannique [Online], XXI-1 | 2016, Online since 20 July 2016, connection on 05 May 2019. URL : http://journals.openedition.org/rfcb/874 ; DOI : 10.4000/ rfcb.874

This text was automatically generated on 5 May 2019.

\section{c) $\$(\Theta$}

Revue française de civilisation britannique est mis à disposition selon les termes de la licence Creative Commons Attribution - Pas d'Utilisation Commerciale - Pas de Modification 4.0 International. 


\title{
Review of Julie V. Gottlieb 'Guilty Women', foreign policy, and appeasement in inter-war Britain.
}

\author{
Marc Calvini Lefebvre
}

\section{REFERENCES}

Julie V Gottlieb, 'Guilty Women', foreign policy, and appeasement in inter-war Britain, Basingstoke and New York, Palgrave Macmillan,340 pages, ISBN : 978-0-230-30429-1, $\$ 69.99$

1 Women's history and gender history share a propensity to fundamentally disrupt wellestablished historical narratives. Yet the emergence of the second has at times been so controversial as to give the impression that feminist historians had to choose between them. Julie Gottlieb's impressive study is a wonderful example of their complementarity and, in her skilful hands, their combination profoundly recasts the familiar story of the "Munich Crisis" of 1938.

2 This feat is achieved by bringing together two questions that are usually kept separate: "did Britain follow a reasonable course in foreign policy in response to the rise of the dictators?" and "[h]ow did women's new citizenship status reshape British politics in the post-suffrage years?" (9). The first is the preserve of appeasement literature: prolific in output but narrow in both its interpretive paradigms and choice of sources, this literature has paid insufficient attention to women as historical actors and to gender as a category of historical analysis. It thus barely registers or questions a widespread view held by contemporaries: that appeasement was a "feminine" policy, both in the (literal) sense of being what women wanted and in the (gendered) sense of lacking the necessary virility to counter the continent's alpha-male dictators. The second question has driven the enquiries of women's historians, whom have neither paid much attention to foreign affairs, a field saturated with male actors, nor to women engaged on the conservative end 
of the political spectrum. This has resulted in a dual blindness: to the elite women who were deeply embroiled in the making or contesting of appeasement, and to the grassroots Conservative women who overwhelmingly supported it.

3 In order to write women back in to the story of what Gottlieb insightfully calls "the People's Crisis", the book is divided into four main parts, each exploring a different group of women: feminists (chapters $1 \& 2$ ), elite and grass-roots party political - mostly Conservative - women (chapters 3, $4 \& 5$ ), ordinary women (chapters $6,7 \& 8$ ), and the women "Churchillians" (chapter 9). The care taken here not to homogenise women, to pay close attention to their social and political locations and the impact of these on their expressions of opinion about the government's foreign policy is a first remarkable feature of this study. Indeed, it allows the author to convincingly dismantle the idea that women supported appeasement qua women, and to identify the origins of this tenacious myth. To disprove it, Gottlieb could have been content with pointing to a series of remarkable women anti-appeasers of the first hour such as the the Duchess of Atholl, formidable antifascist of the right, or the highly articulate feminists Monica Whatley or Eleanore Rathbone who, encountering fascism on their European travels or on British streets, dropped their 1920s campaigning for internationalism and produced a deluge of antifascist literature in the 1930s. But she delves below this illustrious surface, going off the beaten track to seek out new sources from which to glean ordinary women's views on appeasement. The result is a startling cornucopia of source materials - the archives of the Conservative Women's Association, opinion polls, recurring press cartoons, letters written by women to the Chamberlains, Winston Churchill, Duff Cooper and Leo Amery, women's Mass-Observation diaries, commemorative plates sold to Chamberlain's admirers, and the results of 1938's seven by-elections - each treated with considerable care. This tour de force leads to an authoritative conclusion: that although ordinary British women tended on the whole to espouse a deep but uninformed pacifism and to record their sense of significant differences between the sexes over appeasement, it was simply not the case that British women voted systematically as a bloc in favour of appeasement candidates.

Why then, has the dominant frame of interpretation, both at the time and in subsequent decades, been that appeasement was the policy that women wanted? A first answer can be given by turning to women's history: it is very clear that plenty of women did vocally and electorally support appeasement, and Gottlieb meticulously itemises the different groups of these "guilty women". They ranged from socially and politically visible women - those close to Chamberlain (his sisters, his wife, Nancy Astor), aristocratic supporters of Nazism (Lady Londonderry), most Conservative female MPs, and pacifist feminists (Helena Swanwick) - to the ordinary foot soldiers of the Conservative Party and the British Union of Fascists, all the way down to the myriad women (including foreign women) who wrote letters to the Prime Minister to show their support. In the process two central claims of this book emerge. First, that women's exclusion from the institutionally sexist Foreign office was not tantamount to an exclusion from foreign policy making. This is most obvious in the case of elite women, whose interventions via private channels and unofficial diplomacy could be decisive. But it was true also of all women, both ordinary and not, whose letter writing to politicians, Gottlieb insists, must be taken seriously as a form of political expression, precisely because they "otherwise had little access to power" (262). This was their way, via what she helpfully characterises as an "epistolary democracy" (262), of attempting to sway foreign policy. This leads directly to 
her second major claim: that appeasement would not have been implemented, much less maintained, without the staunch loyalty of Conservative women to Chamberlain and his policy, and without the PM's unwavering belief, based on the letters he received, that he was carrying out a policy that women overwhelmingly supported. Blind to the existence of these women, and unaware of the importance of these sources, historians have failed to see how the domestic setting in which Chamberlain operated, and from which he gained emotional sustenance in what were highly stressful times, played a key role in the shaping of his foreign policy.

5 They have also failed to see "how gender mattered" (263) to foreign policy debates and actors. Turning to gender history, Gottlieb throws new light on three phenomena: "public opinion", the place of misogyny in anti-appeasement politics, and the importance of masculinity to foreign policy actors. First, she deftly shows how public opinion was seen after 1918, by politicians and journalists struggling to come to terms with the notion of a feminized democracy, as a feminine force in need of patriarchal guidance. When the elites spoke of "the Public" what they meant was "women" (p.178). And when it came to foreign affairs, particularly questions of war/peace, she establishes convincingly that the dominant view, both in elite and ordinary discourse, remained the pre-war notion that women were "the world's natural pacifists" (154) because of their role as biological and/ or social mothers. Little surprise then that the Government and its backers in the Press saw this feminised public opinion as a dependable source of support and legitimacy for appeasement - and framed their political campaigning and messaging accordingly. Little surprise also that it was denounced by anti-appeasers as guilty of emasculating the country. Indeed, Churchill, his "glamour boys", and their supporters in the Press such as cartoonist David Low were notoriously misogynistic and framed appeasement, "the Public" who allegedly supported it, and male appeasers, as effeminate or under the control of nefarious feminine influences, such as that of Lady Nancy Astor. Gottlieb's proposed interpretation of the attacks on the Cliveden set as motivated by sexism is compelling, as are her arguments that male anti-appeasers are responsible for the writing out of anti-appeasement history of the women they knew and worked with. Equally convincing is her demonstration that competing understandings of masculinity were at play in male actors' own sense of who they were and what they were doing, and in the way they were perceived by the public.

6 Bringing gender and women's history together, Julie Gottlieb has thus provided us with an immensely rich and rewarding analysis of appeasement. My only regret is that there is no separate concluding chapter in which she might have brought the numerous threads of her rich tapestry together to allow readers to see it more clearly and in the round. This might, furthermore, have been an opportunity to expand on one theme, which I personally felt was not as convincingly explored as the rest: the idea that shame was a central emotion in women's, as distinct from men's, turn against appeasement. Indeed, without counterpoints in men's writings, it is difficult for this claim to appear as more than a fruitful hypothesis to pursue. These are however but small quibbles with this work of stunning craftswomanship and path-breaking scholarship. 


\section{AUTHORS}

MARC CALVINI LEFEBVRE

LERMA Université aix Marseilles. 